\title{
Pengaruh Persepsi Sikap, Norma Subjektif dan Persepsi Kontrol Perilaku terhadap Kepatuhan Wajib Pajak Orang Pribadi
}

\author{
Monika Karolina ${ }^{1}$ \\ Naniek Noviari ${ }^{2}$
}

${ }^{1,2}$ Fakultas Ekonomi dan Bisnis Universitas Udayana (Unud), Bali, Indonesia e-mail: monikakarolinaa@gmail.com

\begin{abstract}
ABSTRAK
Tujuan penelitian ini adalah untuk mengetahui pengaruh variabel-variabel dalam theory of planned behavior yaitu persepsi sikap, norma subjektif dan kontrol perilaku terhadap kepatuhan wajib pajak orang pribadi. Penelitian ini dilakukan di KPP Pratama Denpasar Timur dengan 100 wajib pajak orang pribadi yang terdaftar di KPP Pratama Denpasar Timur sebagai sampel dan menggunakan metode non probability sampling, khusunya accidental sampling. Pengumpulan data dilakukan melalui penyebaran kuesioner. Teknik analisis yang digunakan adalah regresi linear berganda. Berdasarkan hasil analisis ditemukan bahwa persepsi sikap, norma subjektif dan persepsi kontrol perilaku berpengaruh secara positif terhadap kepatuhan wajib pajak orang pribadi.

Kata kunci: Kepatuhan Wajib Pajak, Theory of Planned Behavior, Sikap, Norma Subjektif, Persepsi Kontrol Perilaku.
\end{abstract}

\begin{abstract}
The purpose of this research was to determine effect of variabels in theory of planned behavior namely perception of attitude, subjective norm and behavioral control of individual taxpayer compliance. This research was conducted in East Denpasar Primary Tax Office with 100 individual taxpayes registered as a samples and using non probability of sampling method, especially accidental sampling. The data was collected through the distribution of the questionnaire. Analysis techniques that is used is multiple linear regression. Based on the results of the analysis it was found that the perception of the attitude, subjective norms, and perceptions of control behavior had a positively influence individual taxpayer.

Keywords: Compliance taxpayers, theory of planned behavior, attitude, subjective norm, perception of control behavior.
\end{abstract}

\section{PENDAHULUAN}

Kepatuhan perpajakan dapat didefinisikan sebagai suatu keadaan dimana Wajib Pajak memenuhi semua kewajiban perpajakannya sesuai dengan ketentuan peraturan perundang-undangan dan peraturan pelaksanaan perpajakan yang berlaku dalam suatu negara yang dapat diidentifikasi dari kepatuhan wajib pajak 
dalam mendaftarkan diri, kepatuhan pelaporan seperti melaporkan kembali surat pemberitahuan (SPT), kepatuhan dalam perhitungan dan pembayaran tunggakan. Kepatuhan wajib pajak dalam memenuhi kewajiban perpajakannya secara sukarela merupakan tulang punggung dalam self-assessment system yang berlaku di Indonesia. Self-assessment system mewajibkan wajib pajak untuk bertanggungjawab dalam menetapkan sendiri kewajiban perpajakannya dan kemudian membayar dan melaporkan besaran pajak yang dibayarkan secara akurat dan tepat waktu. Pemerintah bertugas untuk mengawasi namun tidak ikut serta menentukan besaran pajak yang harus dibayarkan oleh wajib pajak. Sehingga kepatuhan wajib pajak merupakan salah satu isu penting dalam meningkatkan pendapatan negara khususnya yang bersumber dari perpajakan.

Kepatuhan wajib pajak di Indonesia masih tergolong rendah. Hal ini dapat dilihat pada tax gap di Indonesia yang masih cukup tinggi. Berdasarkan data dari Badan Pusat Statistik (BPS), jumlah penduduk Indonesia yang bekerja mencapai 124,54 juta orang pada tahun 2017. Namun, hanya 36.031 .972 orang yang terdaftar sebagai wajib pajak orang pribadi di dalam sistem administrasi Direktorat Jendral Pajak (DJP) yang berarti bahwa hanya 28,93 persen masyarakat Indonesia yang terdaftar. Dan hanya 16.599.632 yang wajib menyampaikan SPT di tahun 2017 dari total wajib pajak yang terdaftar, namun yang menyampaikan SPT hanya sebesar 9.789 .398 atau 58,97 persen. Data tersebut menunjukkan bahwa terdapat tax gap yang cukup tinggi di Indonesia. Hal ini yang menyebabkan belum optimalnya penerimaan pajak yang diterima negara. 
Rendahnya pembayaran pajak yang merupakan salah satu bentuk dari kepatuhan wajib pajak terjadi di KPP Pratama Denpasar Timur. KPP Pratama Denpasar Timur memiliki jumlah terdaftar wajib pajak yang cukup besar di wilayah Denpasar karena merupakan instansi vertikal dari Direktorat Jenderal Pajak yang membawahi wilayah Kecamatan Denpasar Timur dan Kecamatan Denpasar Selatan. Hal ini dapat dilihat pada Tabel 1.

\section{Tabel 1.}

Tingkat Kepatuhan Wajib Pajak Orang Pribadi di KPP Pratama Denpasar Timur Tahun 2013-2017

\begin{tabular}{|c|c|c|c|c|}
\hline Tahun & $\begin{array}{l}\text { WPOP } \\
\text { Terdaftar } \\
\text { (Orang) }\end{array}$ & $\begin{array}{c}\text { W } \\
\text { POP } \\
\text { Efektif } \\
\text { (Orang) }\end{array}$ & $\begin{array}{c}\text { WPOP yang } \\
\text { Menyampaikan SPT } \\
\text { (Orang) }\end{array}$ & $\begin{array}{r}\text { Tingkat } \\
\text { Kepatuhan }(\%)\end{array}$ \\
\hline 2013 & 91.972 & $988^{66 .}$ & 36.357 & 54,27 \\
\hline 2014 & 96.901 & $908^{71 .}$ & 35.805 & 49,79 \\
\hline 2015 & 102.145 & $150^{77 .}$ & 36.921 & 47,85 \\
\hline 2016 & 110.764 & $318^{84 .}$ & 40.183 & 47,65 \\
\hline 2017 & 114.873 & $532^{86 .}$ & 42.179 & 48,74 \\
\hline
\end{tabular}

Sumber: KPP Pratama Denpasar Timur, 2018

Berdasarkan tabel 1, jumlah wajib pajak orang pribadi di KPP Pratama Denpasar Timur bertambah setiap tahunnya. Jumlah wajib pajak orang pribadi efektif pun juga ikut bertambah setiap tahunnya. Namun ternyata penambahan tersebut tidak terjadi pada wajib pajak orang pribadi yang menyampaikan SPT. Dari 86.532 wajib pajak orang pribadi yang efektif hanya 42.179 wajib pajak orang pribadi yang menyampaikan SPT. Hal ini tentu berdampak kepada tingkat kepatuhan wajib pajak di KPP Pratama Denpasar Timur itu sendiri. Jika dilihat dari tahun 2013-2016, tingkat kepatuhan wajib pajak orang pribadi di KPP Pratama Denpasar Timur menurun setiap tahunnya. Pada tahun 2013, tingkat 
kepatuhan wajib pajak di KPP Pratama Denpasar Timur adalah sebesar 54,27\% namun turun menjadi $49,79 \%$ pada tahun 2014 , turun lagi menjadi $47,85 \%$ pada tahun 2015 dan menurun lagi menjadi 47,65\% pada tahun 2016. Namun di tahun 2017, tingkat kepatuhan wajib pajak di KPP Pratama Denpasar Timur mengalami peningkatan yang tidak signifkan menjadi $48,74 \%$. Ini menandakan bahwa kepatuhan wajib pajak orang pribadi di KPP Pratama Denpasar Timur masih rendah dan berfluktuatif dimana kurang dari setengah jumlah wajib pajak yang melaksanakan kepatuhan wajib pajaknya dengan baik. Hal ini seharusnya tidak terjadi mengingat jumlah wajib pajak terdaftar yang meningkat setiap tahunnya, kepatuhan wajib pajak pun seharusnya juga meningkat.

Kepatuhan wajib pajak dapat dipengaruhi oleh dua jenis faktor yaitu faktor eksternal meliputi hal-hal diluar wajib pajak seperti pelayanan petugas pajak, sanksi perpajakan, dan lain-lain; serta faktor internal wajib pajak yang lebih mengacu ke sisi psikologi wajib pajak seperti kesadaran wajib pajak, persepsi wajib pajak, dan lain-lain. Penelitian ini akan mengkaji lebih dalam mengenai faktor internal wajib pajak yang mempengaruhi kepatuhan wajib pajak. Hal ini dikarenakan peningkatan kepatuhan wajib pajak bukan semata-mata dilakukan hanya dengan reformasi sistem perpajakan tetapi juga perlu melihat ke sisi wajib pajak itu sendiri, bagaimana mereka memutuskan untuk berperilaku patuh atau tidak patuh terhadap kewajiban perpajakannya.

Dalam menjelaskan perilaku kepatuhan wajib pajak beberapa peneliti menggunakan kerangka Theory of Planned Behavior (TPB). Tidak hanya itu, TPB juga telah banyak digunakan dalam penelitian di berbagai bidang studi yang 
berbeda dan terbukti berhasil menjelaskan perilaku (behaviors) tertentu Ajzen (1991) seperti di bidang kesehatan, pilihan rekreasi, psikologi, sosiologi dan teknologi informasi (Ajzen, 1991). Menurut model TPB ini, perilaku seorang individu dipengaruhi oleh variabel sikap terhadap perilaku, norma subjektif dan persepsi kontrol perilaku.

Sikap didefinisikan sebagai kepercayaan seorang individu tentang untung ruginya dari melakukan perilaku tertentu dan keyakinan individu akan konsekuensi dari perilaku yang dilakukan. Keyakinan seorang wajib pajak tentang perilaku kepatuhan akan menghasilkan sebuah bentuk sikap terhadap kepatuhan pajak. Maraknya kasus mafia pajak yang terjadi beberapa tahun silam mengindikasikan bahwa sebagian besar Wajib Pajak memilih untuk melakukan tindakan kecurangan dalam membayar pajak. Kurangnya kesadaran dan pemahaman Wajib Pajak terhadap makna dari membayar pajak yang merupakan kontribusi untuk negara merupakan salah satu alasan hal tersebut dapat terjadi.

Norma Subjektif adalah keyakinan dalam diri seseorang terhadap harapan normatif orang lain yang dijadikan rujukan oleh orang tersebut. Sumber dari kepatuhan Wajib Pajak terdapat dalam diri seseorang dan juga bisa dipengaruhi oleh orang atau kelompok lain. Seorang Wajib Pajak akan mempertimbangkan dampak dari pengaruh orang lain terhadap dirinya atas keputusan untuk mematuhi atau tidak sebuah aturan perpajakan. Sebagai contoh dari kasus mafia pajak yaitu Gayus Tambunan seorang petugas pajak yang bertindak sebagai fasilitator Wajib Pajak memberikan layanan atau jasa kepada klien nya untuk berlaku curang. Dalam kasus lain, teman satu profesi dan orang-orang terdekat Wajib Pajak bisa 
menjadi salah satu pengaruh seorang Wajib Pajak dalam menaati aturan perpajakan atau dengan kata lain kepatuhan perpajakan.

Persepsi kontrol perilaku (perceived behavioral control) merupakan sebuah persepsi kontrol yang dimiliki oleh individu terhadap sebuah perilaku. Dengan adanya sebuah keyakinan dalam diri seseorang atas kontrol yang berupa perasaan atas sulit atau tidaknya melakukan sebuah perilaku akan membentuk sebuah persepsi kontrol. Seorang individu memiliki kontrol dalam dirinya terhadap perilaku atau tindakan yang akan dilakukan yang berkaitan dengan kepatuhan wajib pajak.

Berdasarkan penjelasan di atas, maka perlu dilakukannya penelitian mengenai pengaruh persepsi sikap, norma subjektif, persepsi kontrol perilaku terhadap kepatuhan wajib pajak orang pribadi. Adapun rumusan masalah penelitian ini adalah sebagai berikut : Apakah persepsi sikap berpengaruh terhadap kepatuhan wajib pajak orang pribadi. Apakah norma subjektif berpengaruh terhadap kepatuhan wajib pajak orang pribadi. Apakah persepsi kontrol perilaku berpengaruh terhadap kepatuhan wajib pajak orang pribadi.

Hasil penelitian ini dapat memperluas pengetahuan mengenai pengaruh Persepsi Sikap, Norma Subjektif dan Persepsi Kontrol Perilaku terhadap Kepatuhan Wajib Pajak Orang Pribadi. Selain itu, dapat memberikan informasi kepada pemerintah mengenai faktor-faktor yang mempengaruhi wajib pajak dalam melaksanakan kepatuhan perpajakannya kemudian juga dapat dijadikan bahan pertimbangan untuk membuat kebijakan perpajakan guna meningkatkan kepatuhan perpajak di Indonesia. Sebagai referensi bagi peneliti selanjutnya untuk 
melakukan penelitian kembali pada tahun berikutnya maupun menambah variabel baru untuk memperluas hasil penelitian.

Grand theory yang mendasari penelitian ini adalah Theory of Planned Behavior (TPB). Theory of Planned Behavior didasarkan pada asumsi bahwa manusia akan bertingkah laku sesuai dengan akal sehatnya serta akan mengambil informasi atas tingkah laku tersebut. Teori ini dapat digunakan untuk memprediksi apakah seseorang akan melakukan atau tidak melakukan suatu perilaku. Menurut Theory of Planned Behavior, faktor yang mempengaruhi perilaku terdiri atas tiga determinan dasar, yang bersifat personal, sosial dan kontrol. Bersifat personal adalah sikap, yang bersifat sosial adalah norma subjektif dan yang bersifat kontrol adalah Perceived Behavior Control (PBC).

Pajak merupakan iuran yang dipungut oleh pemerintah terhadap warga negaranya untuk membiayai pengeluaran negara yang berkaitan dengan fasilitasfasilitas untuk warga negara itu sendiri. Pajak sebagai iuran rakyat kepada kas negara berdasarkan undang-undang dengan tidak mendapat jasa timbal balik yang langsung dapat ditunjukkan, dan digunakan untuk membayar pengeluaran umum. Pajak adalah kontribusi wajib kepada negara yang bersifat memaksa dengan tidak mendapatkan imbalan secara langsung dan digunakan untuk keperluan negara sebesar-besarnya bagi kemakmuran rakyat.

Subjek pajak adalah istilah yang digunakan untuk orang pribadi atau badan yang wajib melaksanakan kewajibannya dan mendapatkan haknya dalam peraturan perpajakan. Subjek pajak dari pajak penghasilan adalah orang yang memiliki penghasilan dan mampu menambah kemampuan ekonomis orang yang 
bersangkutan. Dalam perpajakan, yang dimaksud dengan objek pajak yaitu sesuatu yang dikenakan pajak. Objek pajak merupakan dasar pengenaan pajak atau sasaran untuk menghitung pajak terutang.

Wajib Pajak adalah sebutan untuk orang pribadi atau badan, meliputi pembayar pajak, pemotong pajak dan pemungut pajak yang memiliki hak dan kewajiban perpajakan sesuai dengan ketentuan peraturan perundang-undangan perpajakan. Kepatuhan Wajib Pajak diartikan sebagai suatu keadaan di mana Wajib Pajak memenuhi semua kewajiban perpajakan dan mendapatkan hak perpajakannya. Patuh terhadap aturan perpajakan serta paham atas proses pembayaran pajak dengan aktif mencari informasi agar dapat melaporkan dan membayar secara akurat dan tepat waktu.

Sikap merupakan suatu disposisi untuk merespon secara positif atau negatif suatu perilaku. Sikap terhadap perilaku ditentukan oleh belief (keyakinan) tentang konsekuensi dari sebuah perilaku, yang disebut sebagai behavioral beliefs Ajzen (1991). Keyakinan berkaitan dengan penilaian subjektif oleh setiap individu terhadap lingkungan sekitarnya. Keputusan untuk melakukan sebuah perilaku tertentu akan dihubungkan dengan akibat yang bisa ditimbulkan dan dampaknya terhadap lingkungan sekitar. Jika dampak yang dihasilkan memberikan keuntungan bagi dirinya maka keyakinan tersebut dapat memperkuat sikap terhadap perilaku. Dengan begitu setiap individu akan memahami hubungannya dengan lingkungan disekitarnya.

Sikap terhadap kepatuhan pajak adalah seberapa besar keyakinan positif atau negatif wajib pajak atas evaluasinya terhadap hasil berperilaku patuh 
terhadap kewajiban perpajakan. Jika persepsi yang dimiliki oleh wajib pajak menunjukkan hasil yang positif atas sebuah perilaku maka tindakan yang dilakukan dalam kaitannya kepatuhan perpajakan juga akan positif begitu juga dengan sebaliknya (Achmat, 2010).

Dalam TPB, sikap terhadap perilaku (attitude toward behavior) dipengaruhi oleh kepercayaan-kepercayaan perilaku (behavior beliefs). Kerangka penilaian harapan-harapan digunakan sebagai pengukur sikap terhadap suatu perilaku. Norma subjektif dalam penelitian ini merupakan sudut pandang orang lain atau kelompok lain yang dapat mempengaruhi seorang Wajib Pajak dalam memutuskan perilaku yang patuh atau tidak terhadap peraturan perpajakan. Kekuatan dalam diri untuk menghadapi orang lain akan mempengaruhi Wajib Pajak atas pengaruh dari individu lainnya untuk melakukan sebuah tindakan. Dalam kepatuhan Wajib Pajak, referents dapat berasal dari teman, konsultan pajak, petugas pajak serta media cetak dan elektronik.

Persepsi kontrol perilaku merupakan persepsi individu terhadap kesanggupannya dalam melaksanakan sebuah perilaku. Persepsi kontrol perilaku (perceived behavioral control) merupakan kemudahan atau kesulitan untuk melakukan suatu perilaku. Keyakinan individu mengenai ada atau tidaknya faktor yang mendukung atau menghalangi individu untuk memunculkan perilaku tertentu disebut dengan control belief. Belief ini didasarkan pada pengalaan individu terdahulu terhadap sebuah perilaku, informasi yang diperoleh dari proses observasi terhadap sebuah perilaku berdasarkan pengetahuan yang dimiliki maupun lingkungan sekitar serta faktor lain seperti hal-hal yang dapat 
meningkatkan atau menurunkan perasaan seseorang mengenai tingkat kesulitan dalam melakukan sebuah perilaku. Kontrol yang dirasakan akan lebih besar jika terdapat banyak faktor pendukung dengan sedikit penghambat sehingga memudahkan individu untuk melakukan sebuah perilaku.

Berdasarkan penelitian yang telah dilakukan oleh Alvin (2014) mengenai pengaruh sikap, norma subjektif dan kontrol perilaku yang dipersepsikan staff pajak terhadap kepatuhan pajak wajib pajak badan, menemukan bahwa sikap berpengaruh secara positif terhadap kepatuhan Wajib Pajak badan. Begitu juga sebaliknya, Pangestu \& Rusmana (2012) dan Anggita (2014) juga menemukan dalam penelitiannya bahwa sikap berpengaruh terhadap kepatuhan Wajib Pajak. Semakin tinggi atau positif sikap patuh terhadap kewajiban perpajakannya, maka akan berbanding lurus dengan kepatuhan Wajib Pajak tersebut. Dalam hubungannya dengan penelitian ini, persepsi sikap Wajib Pajak memiliki pengaruh yang positif terhadap kepatuhan Wajib Pajak untuk berperilaku. Sikap positif akan terbentuk ketika wajib pajak menyadari bahwa membayar pajak merupakan hal yang penting dan bermanfaat, sebaliknya sikap negatif terbentuk ketika wajib pajak tidak menyadari hal tersebut. Dengan adanya dukungan baik itu mendukung secara positif (favorable) atau secara negatif (unfavorable), tentu ini akan berpengaruh terhadap kepatuhan Wajib Pajak. Wajib Pajak yang memiliki persepsi sikap mendukung terhadap perilaku patuh terhadap kewajiban perpajakannya akan patuh terhadap kewajiban perpajakannya. Begitu juga dengan Wajib Pajak yang memiliki persepsi sikap yang tidak mendukung terhadap perilaku patuh terhadap kewajiban perpajakannya juga akan tidak patuh terhadap 
kewajiban perpajakannya.

Berdasarkan pemahaman di atas, maka dapat dirumuskan hipotesis penelitian sebagai berikut.

$\mathrm{H}_{1}$ : Persepsi Sikap berpengaruh terhadap Kepatuhan Wajib Pajak Orang Pribadi.

Norma subjektif adalah faktor penentu kedua yang mempengaruhi perilaku patuh wajib pajak dalam Theory of Planned Behavior. Norma subyektif adalah persepsi individu tentang pengaruh sosial dalam membentuk perilaku tertentu (Ajzen, 1991). Pihak-pihak dari kelompok atau individu lain akan memberikan tekanan sosial yang menjadikan individu tersebut merasa pandangan ataupun respon dari pihak tersebut dapat dijadikan pertimbangan dalam berperilaku. Jika pihak-pihak tersebut mendukung individu tersebut dalam melakukan suatu perilaku, maka individu tersebut akan cenderung melakukan perilaku tersebut, begitu juga sebaliknya.

Hal tersebut juga dinyatakan dalam kesimpulan penelitian Alvin (2014) bahwa variabel norma subjektif berpengaruh secara positif terhadap kepatuhan Wajib Pajak badan. Hal tersebut mengindikasikan bahwa semakin besar tekanan yang diberikan oleh lingkungan responden untuk tidak mematuhi aturan perpajakan maka individu tersebut akan cenderung untuk melakukan hal yang sama, begitu juga dengan sebaliknya. Kepatuhan seseorang terhadap perpajakan dipengaruhi oleh berbagai hal selain diri sendiri antara lain lingkungan maupun orang atau kelompok lain yang meliputi keluarga, teman terdekat serta petugas pajak. Hal ini dikarenakan pihak-pihak tersebut merupakan pihak-pihak sekitar Wajib Pajak yang akan mempengaruhi Wajib Pajak dalam melaksanakan 
kewajiban perpajakannya (Anggita, 2014). Semakin tinggi respon positif perilaku patuh pajak dari referents (norma subjektif tinggi), maka perilaku kepatuhan Wajib Pajak juga akan semakin meningkat. Begitu juga semakin rendah respon positif perilaku patuh pajak dari referents (norma subjektif rendah), maka perilaku kepatuhan Wajib Pajak juga akan menurun.

Berdasarkan pemahaman di atas, maka dapat dirumuskan hipotesis penelitian sebagai berikut:

$\mathrm{H}_{2}$ : Norma Subjektif berpengaruh terhadap Kepatuhan Wajib Pajak Orang Pribadi.

Faktor penentu perilaku ketiga sesuai dengan theory of planned behavior adalah persepsi kontrol perilaku. Persepsi kontrol perilaku merupakan kemampuan individu atas mudah atau tidaknya melakukan sesuatu. Keyakinan individu mengenai ada atau tidaknya faktor yang mendukung atau menghalangi individu untuk memunculkan perilaku tertentu disebut dengan control belief. Belief ini didasarkan pada pengalaan individu terdahulu terhadap sebuah perilaku, informasi yang diperoleh dari proses observasi terhadap sebuah perilaku berdasarkan pengetahuan yang dimiliki maupun lingkungan sekitar, dan juga oleh berbagai faktor lain yang dapat meningkatkan ataupun menurunkan perasaan individu mengenai tingkat kesulitan dalam melakukan sebuah perilaku.

Menurut Alvin (2014) dalam penelitiannya, kontrol perilaku yang dipersepsikan yang dimiliki oleh seorang staff pajak berpengaruh positif terhadap kepatuhan pajak dari wajib pajak badan tersebut secara signifikan. Putri (2014) juga dalam penelitiannya menemukan bahwa persepsi kontrol perilaku berpengaruh secara positif dan signifikan terhadap kepatuhan wajib pajak orang 
pribadi di kota Yogyakarta. Wajib Pajak akan memiliki berperilaku patuh terhadap kewajiban perpajakannya apabila ia merasa sanggup untuk berperilaku patuh (persepsi kontrol perilaku tinggi).

Persepsi kontrol perilaku dalam konteks kepatuhan wajib pajak merupakan besarnya tingkat kendali oleh wajib pajak orang pribadi dalam menaati peraturan perpajakan. Persepsi tersebut akan memberikan motivasi terhadap individu itu sendiri untuk melakukan sebuah tindakan. Misalnya saja, jika Wajib Pajak tidak merasa kesulitan dalam mengisi SPT dan merasa mampu secara finansial untuk membayar pajak, maka Wajib Pajak tersebut akan cenderung patuh terhadap kewajiban perpajakannya. Jika dikaitkan dengan penelitian ini kepatuhan akan terbentuk apabila Wajib Pajak merasa mampu untuk berperilaku patuh terhadap kewajiban perpajakannya. Semakin banyak faktor pendukung dan sedikit penghambat untuk melakukan suatu perilaku (persepsi kontrol perilaku tinggi), maka akan semakin mudah bagi Wajib Pajak untuk berperilaku patuh terhadap kewajiban perpajakannya. Begitu juga jika semakin banyak faktor penghambat untuk melakukan suatu perilaku (persepsi kontrol perilaku rendah), maka akan semakin sulit bagi Wajib Pajak untuk berperilaku patuh terhadap kewajiban perpajakannya.

Berdasarkan pemahaman di atas, maka dapat dirumuskan hipotesis penelitian sebagai berikut:

$\mathrm{H}_{3}$ : Persepsi Kontrol Perilaku Berpengaruh terhadap Kepatuhan Wajib Pajak Orang Pribadi. 
Monika Karolina dan Naniek Noviari. Pengaruh ...

\section{METODE PENELITIAN}

Jenis penelitian yang dilakukan ini adalah penelitian kausal komparatif yang bertujuan untuk menyelidiki kemungkinan hubungan sebab akibat dengan menggunakan pendekatan kuantitatif. Metode penelitian ini berlandaskan pada filsafat positivisme yang digunakan untuk meneliti pada populasi atau sampel tertentu, menggunakan instrumen penelitian untuk pengumpulan data dengan analisis data yang bersifat kuantitatif/statistik. Penelitian ini bertujuan untuk mengetahui hubungan variabel dalam Theory of Planned Behavior yaitu persepsi sikap, norma subjektif dan persepsi kontrol perilaku terhadap kepatuhan Wajib Pajak Orang Pribadi di KPP Pratama Denpasar Timur. Penelitian ini dilakukan di Kantor Pelayanan Pajak (KPP) Pratama Denpasar Timur yang beralamat di Jalan Tantular No. 4 Renon, Denpasar Timur.

Obyek dalam penelitian ini adalah kepatuhan wajib pajak orang pribadi di KPP Pratama Denpasar Timur. Data primer diperoleh dari jawaban terhadap serangkaian pertanyaan kuesioner yang diajukan oleh peneliti mengenai faktorfaktor yang memengaruhi kepatuhan wajib pajak orang pribadi terhadap wajib pajak orang pribadi yang terdaftar di KPP Pratama Denpasar Timur. Data sekunder pada penelitian ini yaitu data wajib pajak orang pribadi dan data tingkat kepatuhan dari SPT tahunan wajib pajak orang pribadi di KPP Pratama Denpasar Timur.

Populasi dalam penelitian ini adalah jumlah wajib pajak orang pribadi efektif sebanyak 86.532 wajib pajak orang pribadi yang terdaftar di KPP Pratama Denpasar Timur tahun 2017. Pengambilan sampel dalam penelitian ini 
menggunakan teknik non probability sampling atau yang juga dikenal dengan nama sampel non probabilitas. Jenis sampling yang dipilih adalah accidental sampling dengan kriteria sampel merupakan wajib pajak orang pribadi efektif yang terdaftar di KPP Pratama Denpasar Timur.

Besarnya jumlah sampel dihitung menggunakan formula statistik pendekatan Yamane yaitu:

$$
\mathrm{n}=\frac{\mathrm{N}}{\mathrm{N} \cdot \mathrm{d}^{2}+1}
$$

Keterangan:

$\mathrm{n} \quad=$ Jumlah Sampel

$\mathrm{N} \quad=$ Jumlah Populasi

$\mathrm{d}^{2} \quad=$ presisi (ditetapkan $10 \%$ dengan tingkat kepercayaan 90\%)

Berdasarkan rumus tersebut maka diperoleh jumlah sampel penelitian sebagai berikut:

$$
\left.\mathrm{n}=\frac{\mathrm{N}}{\mathrm{N} \cdot \mathrm{d}^{2}+1}=\frac{86.532}{\left(86.532 \times 0,1^{2}\right)+1}=99,87 \text { (100 responden }\right)
$$

Metode pengumpulan data yang digunakan dalam penelitian ini adalah penyebaran kuesioner kepada responden yang merupakan sampel penelitian. Teknik analisis data yang digunakan adalah teknik analisis regresi linier berganda untuk mengukur pengaruh antara lebih dari satu variabel bebas pada variabel terikat (Ghozali, 2016). Analisis regresi linier berganda (multiple linear regression) digunakan untuk menguji hipotesis yang ada, yaitu untuk melihat pengaruh variabel persepsi sikap, norma subjektif dan persepsi kontrol perilaku terhadap kepatuhan wajib pajak orang pribadi. Model regresi dalam penelitian ini 
dinyatakan sebagai berikut :

$$
Y=a+b_{1} X_{1}+b_{2} X_{2}+b_{3} X_{3}+e
$$

Keterangan:

$\mathrm{Y} \quad=$ Kepatuhan Wajib Pajak Orang Pribadi

a $\quad=$ konstanta

$\mathrm{b} \quad=$ Koefisien Regresi Variabel

$\mathrm{X}_{1} \quad=$ Persepsi Sikap

$\mathrm{X}_{2} \quad=$ Norma Subjektif

$\mathrm{X}_{3} \quad=$ Persepsi Kontrol Perilaku

$\mathrm{e}=$ standar error

Selanjutnya diakukan uji asumsi klasik seperti uji normalitas, uji heterokedastisitas, dan uji multikolinearitas.

\section{HASIL DAN PEMBAHASAN}

Penelitian ini menggunakan data primer berupa kuesioner yang disebarkan langsung ke responden penelitian yaitu wajib pajak orang pribadi efektif yang terdaftar di KPP Pratama Denpasar Timur. Kuesioner disebarkan secara langsung ke responden penelitian yaitu dengan menyerahkan kuesioner ke responden yang peneliti temui di KPP Pratama Denpasar Timur. Jumlah kuesioner yang disebarkan adalah sebanyak 100 kuesioner dan kuesioner yang kembali sebanyak 100. Secara rinci hasil penyebaran dan pengembalian kuesioner penelitian dapat dilihat dalam Tabel 2.

Tabel 2.

Distribusi Kuesioner

\begin{tabular}{lc}
\multicolumn{1}{c}{ Keterangan } & Jumlah \\
\hline Kuisioner Yang Tersebar & 100 \\
Kuesioner Yang Tidak Kembali & 0 \\
Kuesioner Yang Tidak Memenuhi Kriteria & 0 \\
Kuesioner Yang Dapat Digunakan & 100 \\
Tingkat Pengembalian & $100 \%$ \\
\hline
\end{tabular}

Sumber : Data diolah, 2018.

Karakteristik responden dalam penelitian ini dibagi menjadi beberapa 
kelompok yaitu menurut jenis kelamin, umur dan jenis pekerjaan.

Tabel 3.

Karakteristik Responden Berdasarkan Jenis Kelamin

\begin{tabular}{ccc}
\hline Jenis Kelamin & Jumlah & Persentase \\
\hline Laki - laki & 51 & $51 \%$ \\
Perempuan & 49 & $49 \%$ \\
Total & 100 & $100 \%$ \\
\hline
\end{tabular}

Sumber : Data diolah, 2018

Berdasarkan data pada Tabel 3, dapat diketahui bahwa responden dalam penelitian ini sebagian besar merupakan berjenis kelamin laki-laki. Di antara 100 (seratus) orang responden, 51 orang merupakan laki-laki dengan persetanse $51 \%$ dan sisanya sebanyak 49 orang adalah perempuan dengan persentase $49 \%$. Meskipun perbedaannya tidak terlalu signifikan, namun responden dalam penelitian ini sebagian besar adalah laki-laki.

Tabel 4.

Karakteristik Responden Berdasarkan Umur

\begin{tabular}{ccc}
\hline Umur & Jumlah & Persentase \\
\hline $20-29$ tahun & 24 & $24 \%$ \\
$30-39$ tahun & 33 & $33 \%$ \\
$40-49$ tahun & 33 & $33 \%$ \\
$50-59$ tahun & 6 & $6 \%$ \\
$>=60$ tahun & 4 & $4 \%$ \\
Total & 100 & $100 \%$ \\
\hline
\end{tabular}

Sumber : Data diolah, 2018.

Berdasarkan Tabel 4, karakteristik responden berdasarkan umur dalam penelitian ini terbagi menjadi 5 (lima) kelompok, yaitu usia antara 20 - 29 tahun, 30 - 39 tahun, 40 - 49 tahun, 50 - 59 tahun dan di atas 60 tahun. Responden yang 
berusia antara $20-29$ tahun terdiri dari 24 orang dengan persentase $24 \%$, kelompok usia antara 30 - 39 tahun dan 40 - 49 tahun masing-masing terdiri dari 33 orang dengan persentase 33\%, usia antara 50 - 59 tahun hanya terdiri dari 6 orang (6\%) dan yang berusia di atas 60 tahun terdiri dari 4 orang saja (4\%). Responden dalam penelitian ini didominasi oleh kelompok usia 30 - 39 tahun dan 40 - 49 tahun yang masing-masing sebanyak 33\%. Hal ini menunjukkan bahwa mayoritas responden dalam penelitian ini berusia dewasa dan produktif yaitu kisaran usia $30-49$ tahun.

Tabel 5.

Karakteristik Responden Berdasarkan Jenis Pekerjaan

\begin{tabular}{ccc}
\hline Jenis Pekerjaan & Jumlah & Persentase \\
\hline Pegawai Negeri Sipil & 26 & $26 \%$ \\
Pegawai Swasta & 65 & $65 \%$ \\
Lainnya & 9 & $9 \%$ \\
Total & 100 & $100 \%$ \\
\hline
\end{tabular}

Sumber : Data diolah, 2018.

Berdasarkan Tabel 5, karakteristik responden berdasarkan jenis pekerjaannya dalam penelitian ini terdiri atas 3 (tiga) kelompok yaitu Pegawai Negeri Sipil, Pegawai Swasta dan Lainnya (Non Karyawan). Responden yang bekerja sebagai pegawai negeri sipil berjumlah 26 orang dengan persentase $26 \%$. Sedangkan untuk responden yang bekerja sebagai pegawai swasta adalah sebanyak 65 orang dengan persentase $65 \%$. Selain itu, terdapat pula 9 orang responden $(9 \%)$ yang termasuk non-karyawan, dimana 3 orang memiliki usaha dagang, 3 orang memiliki usaha jasa, 2 orang merupakan pensiunan dan 1 orang 
memiliki pekerjaan profesi. Berdasarkan informasi tersebut, maka dapat diketahui bahwa sebagian besar responden dalam penelitian ini berprofesi sebagai karyawan swasta.

Rata-rata dan standar deviasi ideal dihitung menggunakan rumus berikut.

Mean Ideal $(M i)=\frac{\text { skor maksimum ideal }+ \text { skor minimum ideal }}{2}$

Standar Deviasi Ideal $(S d i)=\frac{\text { skor maksimum ideal-skor minimum ideal }}{6}$

Hasil uji statistik deskriptif dapat dilihat pada Tabel 6.

Tabel 6.

Hasil Uji Statistik Deskriptif

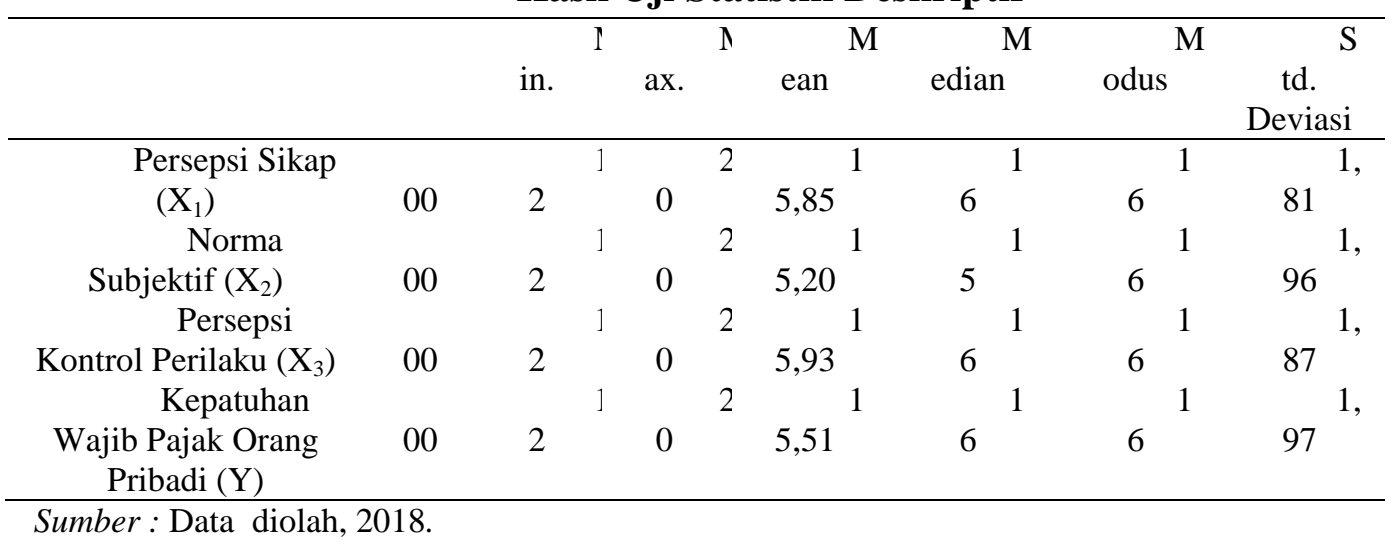

Pada variabel Persepsi Sikap, nilai minimalnya adalah 12 dan nilai maksimalnya adalah 20 dengan median 16, mean 15,85, modus 16 dan standar deviasi 1,81. Variabel Norma Subjektif, nilai minimalnya adalah 12 dan nilai maksimalnya adalah 20 dengan median 15, mean 15,20, modus 16 dan standar deviasi 1,96. Variabel Persepsi Kontrol Perilaku, nilai minimalnya adalah 12 dan nilai maksimalnya adalah 20 dengan median 16, mean 15,93, modus 16 dan standar deviasi 1,87. Pada variabel Kepatuhan Wajib Pajak Orang Pribadi, nilai 
minimalnya adalah 12 dan nilai maksimalnya adalah 20 dengan median 16, mean 15,51, modus 16 dan standar deviasi 1,97.

Tabel 7.

\section{Hasil Uji Asumsi Klasik}

\begin{tabular}{|c|c|c|c|c|}
\hline \multirow{2}{*}{$\begin{array}{l}\text { Parameter Yang } \\
\text { Diuji }\end{array}$} & \multirow{2}{*}{$\begin{array}{c}\text { Uji } \\
\text { Normalitas } \\
\begin{array}{c}\text { Asym } \\
\text { p. Sig. }(2- \\
\text { tailed) }\end{array} \\
\end{array}$} & \multirow{2}{*}{$\begin{array}{c}\text { Uji } \\
\begin{array}{c}\text { Heteroskedasti } \\
\text { sitas }\end{array} \\
\text { Sig. }\end{array}$} & \multicolumn{2}{|c|}{ Uji Multikolinearitas } \\
\hline & & & Tolerance & $\mathrm{F}^{\mathrm{VI}}$ \\
\hline $\begin{array}{l}\text { Unstandarized } \\
\text { Residual }\end{array}$ & 0,589 & & & \\
\hline Persepsi Sikap (X1) & & 0,750 & 0,864 & $58^{1,1}$ \\
\hline (X2) Norma Subjektif & & 0,861 & 0,563 & \\
\hline $\begin{array}{l}\text { Persepsi Kontrol } \\
\text { Prilaku (X3) }\end{array}$ & & 0,338 & 0,561 & $82^{1,7}$ \\
\hline
\end{tabular}

Hasil uji normalitas pada tabel 7 menunjukkan bahwa nilai Asymp. Sig (2tailed) sebesar 0,589. Nilai ini lebih besar dari level of significant yaitu 0,10. Hal ini menandakan bahwa model regresi yang digunakan dalam penelitian ini berdistribusi normal. Nilai signifikansi semua variabel bebas berada di atas level of significant yaitu 0,10 . Hal ini menandakan tidak terjadi heterokedastisitas. Nilai tolerance dari setiap variabel independen semuanya tidak ada yang kurang dari 0,10 . Begitu juga pada hasil perhitungan nilai VIF dari setiap variabel independen dalam penelitian ini tidak ada yang melebihi 10. Hal ini menandakan bahwa tidak ada multikolinearitas antar variabel independen dalam model regresi. 
Tabel 8.

Hasil Uji Analisis Regresi Linear Berganda

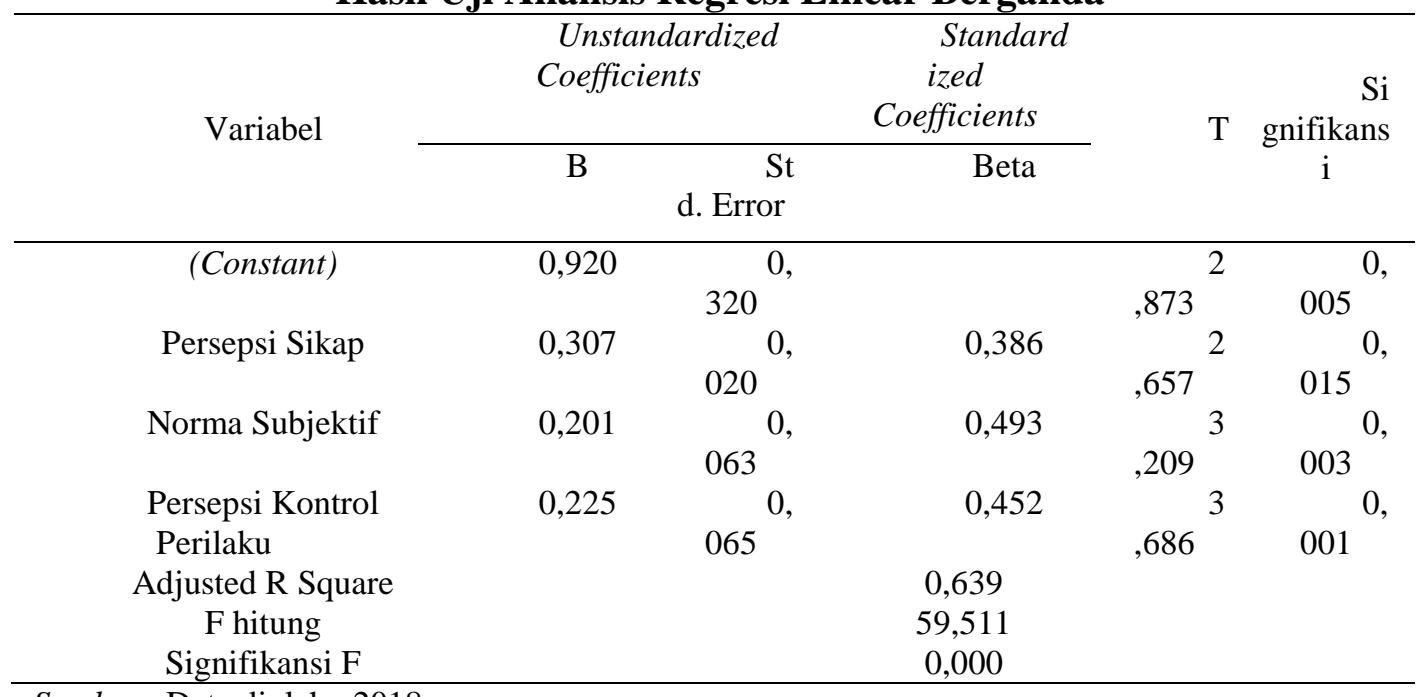

Sumber : Data diolah , 2018

Berdasarkan Tabel 8 di atas, model regresi berganda yang terbentuk pada penelitian ini adalah sebagai berikut.

$$
Y=0.920+0.307 X_{1}+0.201 X_{2}+0.225 X_{3}+e
$$

Berdasarkan persamaan di atas, dapat dijelaskan hal-hal sebagai berikut:

Nilai koefisien $\beta 1$ bernilai positif sebesar 0.307 memiliki arti bahwa terdapat pengaruh antara Persepsi Sikap $\left(X_{1}\right)$ terhadap Kepatuhan Wajib Pajak Orang Pribadi dimana jika Persepsi Sikap naik satu satuan maka Kepatuhan Wajib Pajak Orang Pribadi (Y) akan naik sebesar 0.307, jika nilai variabel Norma Subjektif dan Persepsi Kontrol Perilaku dipertahankan konstan.

Nilai koefisien $\beta 2$ bernilai positif sebesar 0.201 memiliki arti bahwa variabel Norma Subjektif $\left(\mathrm{X}_{2}\right)$ memengaruhi Kepatuhan Wajib Pajak Orang Pribadi (Y) dimana jika Norma Subjektif $\left(\mathrm{X}_{2}\right)$ naik satu satuan maka Kepatuhan 
Wajib Pajak Orang Pribadi (Y) akan naik sebesar 0.201, jika nilai variabel Persepsi Sikap dan Persepsi Kontrol Perilaku dipertahankan konstan.

Nilai koefisien $\beta 3$ bernilai positif sebesar 0.225 memiliki arti bahwa variabel Persepsi Kontrol Perilaku $\left(\mathrm{X}_{3}\right)$ memengaruhi Kepatuhan Wajib Pajak Orang Pribadi (Y) dimana jika Persepsi Kontrol Perilaku $\left(\mathrm{X}_{3}\right)$ naik satu satuan maka Kepatuhan Wajib Pajak Orang Pribadi (Y) akan naik sebesar 0,225, jika nilai variabel Persepsi Sikap dan Norma Subjektif dipertahankan konstan.

Nilai koefisien determinasi yang diperoleh berdasarkan Tabel 8 adalah sebesar 0.639 . Sehingga nilai determinasinya menjadi $0.639 \times 100 \%=63.9 \%$. Hal ini mengindikasikan bahwa Kepatuhan Wajib Pajak Orang Pribadi 63,9\% dipengaruhi oleh variabel Persepsi Sikap, Norma Subjektif dan Persepsi Kontrol Perilaku sisanya dipengaruhi oleh variabel lain yang tidak dimasukkan ke dalam model.

Pada Tabel 8 dapat dilihat nilai signifikan sebesar 0.000 atau $<0,10$. Hal ini menunjukkan bahwa model regresi linear berganda yang digunakan untuk menguji pengaruh variabel independen terhadap variabel dependen layak digunakan.

Hasil uji hipotesis pertama menunjukkan bahwa Persepsi Sikap berpengaruh positif terhadap Kepatuhan Wajib Pajak Orang Pribadi di KPP Pratama Denpasar Timur. Hal ini dapat dilihat dari nilai signifikansi t sebesar 0,015 yang lebih kecil dari nilai $\alpha=0,10$. Hasil penelitian ini sejalan dengan hasil penelitian yang dilakukan oleh Putri (2014) yaitu persepsi sikap berpengaruh positif terhadap kepatuhan wajib pajak. 
Theory of planned behavior manyatakan bahwa persepsi sikap memiliki peranan penting dalam menjelaskan perilaku seseorang dalam lingkungannya. Persepsi sikap merupakan keyakinan yang berkaitan dengan penilaian subjektif oleh setiap individu terhadap lingkungan sekitarnya, menghubungkan antara perilaku tertentu dengan berbagai akibat yang akan diperoleh apabila memutuskan untuk melakukan sebuah tindakan atau tidak merupakan cara untuk memahami hubungan antara diri sendiri dengan lingkungan. Menurut Ajzen (1991) semakin positif persepsi sikap seseorang terhadap suatu perilaku, maka akan semakin tinggi pula kecendrungan individu tersebut untuk berperilaku tertentu. Persepsi sikap positif yang semakin tinggi atas perpajakan akan sejalan dengan kepatuhan perpajakan yang semakin baik pula. Hal ini dikarenakan ketika wajib pajak merasa bahwa membayar pajak itu bermanfaat bagi dirinya dan ia menilai positif atau memihak sikap untuk patuh terhadap kewajiban perpajakannya, maka hal ini akan mendorong wajib pajak tersebut untuk berperilaku patuh terhadap kewajiban perpajakannya.

Hasil uji hipotesis kedua menunjukkan bahwa norma subjektif berpengaruh secara positif terhadap kepatuhan wajib pajak orang pribadi di KPP Pratama Denpasar Timur. Hal ini dapat dilihat dari nilai signifikansi t sebesar 0,003 yang lebih kecil dari nilai $\alpha=0,10$. Hasil penelitian ini sejalan dengan hasil penelitian yang dilakukan oleh Putri (2014) dan Alvin (2014) yang menyatakan bahwa norma subjektif berpengaruh positif terhadap kepatuhan wajib pajak.

Sesuai dengan penjelasan dalam theory of planned behavior, seorang individu juga mempertimbangkan tekanan sosial dari pihak-pihak tertentu dalam 
memutuskan untuk berperilaku tertentu. Jika pihak-pihak tersebut mendukung individu tersebut untuk melakukan suatu perilaku tertentu maka hal ini akan meningkatkan kecenderungan individu tersebut untuk berperilaku tertentu. Dalam penelitian ini, selain wajib pajak itu sendiri, kepatuhan seseorang terhadap kewajiban perpajakannya juga dipengaruhi oleh lingkungan baik itu sekelompok atau individu lain di sekitar wajib pajak. Pihak-pihak yang berada di sekitar wajib pajak merupakan orang-orang yang berpengaruh bagi wajib pajak tersebut dan dapat memberikan tekanan sosial kepada wajib pajak tersebut untuk memunculkan suatu perilaku baik itu patuh atau tidak patuh terhadap kewajiban perpajakannya. Dalam penelitian ini, yang dapat dikatakan pihak-pihak sekitar wajib pajak adalah keluarga, teman dan petugas pajak. Seorang wajib pajak akan menaati peraturan perpajakan jika pihak-pihak sekitarnya memberikan dorongan yang positif untuk patuh terhadap peraturan perpajakan.

Hasil uji hipotesis ketiga menunjukkan bahwa persepsi kontrol perilaku berpengaruh secara positif terhadap kepatuhan wajib pajak orang pribadi di KPP Pratama Denpasar Timur. Hal ini dapat dilihat dari nilai signifikansi t sebesar 0,001 yang lebih kecil dari nilai $\alpha=0,10$. Hasil penelitian ini sejalan dengan hasil penelitian Putri (2014) dan Alvin (2014) yang menunjukkan bahwa persepsi kontrol perilaku berpengaruh terhadap kepatuhan wajib pajak.

Persepsi kontrol perilaku merupakan faktor penentu perilaku ketiga dalam theory of planned behavior. Persepsi kontrol perilaku adalah kontrol dalam diri individu yang berasal dari pengalaman di masa lalu atas keputusan untuk melakukan sebuah tindakan atau perilaku. Semakin tinggi persepsi kontrol 
perilaku yang dimiliki oleh seorang individu, maka semakin tinggi pula kecenderungan individu tersebut untuk berperilaku tertentu. Dalam penelitian ini, persepsi kontrol perilaku wajib pajak juga menentukan wajib pajak tersebut apakah ia akan patuh atau tidak patuh terhadap kewajiban perpajakannya. Semakin tinggi persepsi kontrol perilaku wajib pajak akan meningkatkan kepatuhan perpajakannya.

\section{SIMPULAN}

Berdasarkan hasil analisis dan pembahasan yang telah dipaparkan dalam bab sebelumnya, maka dapat ditarik kesimpulan sebagai berikut. Persepsi sikap berpengaruh positif terhadap kepatuhan wajib pajak orang pribadi di KPP Pratama Denpasar Timur. Norma subjektif berpengaruh positif terhadap kepatuhan wajib pajak orang pribadi di KPP Pratama Denpasar Timur. Persepsi kontrol perilaku berpengaruh positif terhadap kepatuhan wajib pajak orang pribadi di KPP Pratama Denpasar Timur.

Berdasarkan kesimpulan hasil penelitian yang telah dipaparkan di atas, peneliti mengajukan beberapa saran yang dapat dijadikan bahan pertimbangan dan dapat dijadikan masukan bagi pihak terkait khususnya dalam hal meningkatkan kepatuhan pajak antara lain. Berdasarkan hasil tabulasi data kuesioner, dalam bagian pertama mengenai variabel Persepsi Sikap, pernyataan "Saya merasa takut akan resiko dikenai sanksi jika tidak memenuhi kewajiban perpajakan saya" memiliki jumlah skor yang paling rendah. Ini menandakan wajib pajak masih belum paham dan takut terhadap resiko sanksi perpajakan 
sehingga sebaiknya pemerintah menunjukkan kepada masyarakat bahwa wajib pajak yang tidak melakukan kewajiban perpajakannya dengan baik akan disanksi secara tegas. Dalam bagian kedua mengenai variabel Norma Subjektif, pernyataan "Petugas pajak memberikan informasi mengenai resiko tidak membayar pajak kepada saya" memiliki jumlah skor yang paling rendah sehingga petugas pajak di KPP Pratama Denpasar Timur sebaiknya lebih persuasif lagi dalam menginformasikan kepada wajib pajak mengenai resiko tidak membayar pajak.

\section{REFERENSI}

Achmat, Z. (2010). Theory of Planned Behavior, Masihkah Relevan?

Ajzen, I. (1991). Organizational Behavior and Human Decision Process.

Alvin, A. (2014). Pengaruh Sikap, Norma Subjektif, Kontrol Perilaku yang Dipersepsikan Staff Pajak terhadap Kepatuhan Pajak Wajib Pajak Badan. Tax \& Accounting Review, 1(4).

Anggita, L. (2014). Pengaruh Sikap, Norma Subjektif dan Kontrol Keperilakuan yang Dipersepsikan terhadap Niat Berperilaku Patuh Pajak. E-Journal Universitas Pendidikan Indonesia.

Apriany, F. (2013). Studi Evaluasi Kepatuhan Wajib Pajak Sebelum dan Sesudah Sunset Policy (Studi Kasus Wajib Pajak Orang Pribadi pada KPP Pratama Makassar Utara). Jurnal Universitas Makassar Utara.

Aryandini, S. (2016). Pengaruh Kewajiban Moral, Pemeriksaan Pajak dan Kondisi Keuangan terhadap Kepatuhan Wajib Pajak Badan untuk Usaha Hotel yang Terdaftar di Dinas Pendapatan Daerah Kota Pekanbaru. JOM Fekon, 1(3), 1463-1477.

Blanthorne, C. M. (2000). The Role of Opportunity and Beliefs on Tax Evasion: A Structural Equation Analysis. Arizona State: Bell \& Howell Information and Learning Company.

Culiberg, B., and Bajde, D. (2014). Do You Need a Receipt? Exploring Consumer Participation in Consumption Tax Evasion as an Ethical Dilemma. Journal of Business Ethics, 124, 271-282. 
Feby, E. W. (2014). Pengaruh Sikap Ketidakpatuhan Pajak, Norma Subjektif, Kontrol Perilaku yang Dipersepsikan terhadap Niat Wajib Pajak Orang Pribadi untuk Melakukan Penggelapan Pajak. Tax \& Accounting Review, 1(4).

Ghozali, I. (2016). Aplikasi Analisis Multivariete dengan Program IBM SPSS 23 (8th ed.). Semarang: Undip.

Gunawan, A. (2016). Pengaruh Persepsi Tax Amnesty, Pertumbuhan Ekonomi dan Transformasi Kelembagaan Direktorat Jendral Pajak pada Penerimaan Pajak. E-Jurnal Akuntansi Universitas Udayana, 3(17), 2036-2060.

Hendeson, S. E. (2005). An Examination of the Role of Ethics in Tax Compliance Decisions. Journal of The American Taxation Association, 1(27), 38-72.

Indriantoro, N dan Bambang, S. (2002). Metodologi Penelitian Bisnis untuk Akuntansi dan Manajemen. Yogyakarta: BPFE.

Kementerian Keuangan Republik Indonesia. (2016). Keterangan Pers Anggaran Pendapatan dan Belanja Negara Tahun. Jakarta.

Kementrian Keuangan Republik Indonesia. (2016). Keterangan Pers Evaluasi Amnesti Pajak Periode Pertama dan Strategi Periode Kedua dan Ketiga. Jakarta.

Langham, N. C. E. (2012). Improving Tax Compliance Strategies: Can The Theory of Planned Behaviour Predict Business Compliance. Journal of Tax Research, 2(10).

Monic, D. A. (2011). Pengaruh Pemanfaatan Fasilitas Perpajakan Sunset Policy Terhadap Tingkat Kepatuhan Wajib Pajak. Journal Universitas Diponegoro.

Mustikasari, E. (2007). Kajian Empiris Tentang Kepatuhan Wajib Pajak Badan di Perusahaan Industri Pengolahan di Surabaya. Simposium Nasional Akuntansi X.

Mutia, F. A. (2016). Pengaruh Moral Pajak dan Budaya Pajak terhadap Kepatuhan Pajak. Jurnal Universitas Komputer Indonesia.

Ngadiman, D. H. (2015). Pengaruh Sunset Policy, Tax Amnesty, dan Sanksi Pajak terhadap Kepatuhan Wajib Pajak (Studi Empiris di Kantor Pelayanan Pajak Pratama Jakarta Kembangan). Jurnal Akuntansi, 2(14), 225-241.

Pangestu, F., \& Rusmana, O. (2012). Analisis Faktor-faktor yang Berpengaruh 
Terhadap Tax Compliance Penyetoran SPT Masa. Jurnal Universitas Jenderal Soedirman Purwokerto.

Putri, L. Y. (2014). Pengaruh Sikap, Norma Subjektif, Kontrol Keperilakuan yang Dipersepsikan terhadap Kepatuhan Wajib Pajak Orang Pribadi di Kota Yogyakarta. Skripsi Fakultas Ekonomi Universitas Negeri Yogyakarta.

Sugiyono. (2012). Metode Penelitian Kuantitatif Kualitatif dan $R \& D$. Bandung: Alfabeta.

Sugiyono. (2014). Metode Penelitian Bisnis. Bandung: Alfabeta.

Utami, C. D. dan Devano, S. (2016). Pengaruh Persepsi Wajib Pajak Atas Penerapan Penghapusan Sanksi Administrasi Tahun 2015 terhadap Niat Kepatuhan Perpajakan. Simposium Nasional Akuntansi XIX.

Widi, D. E. (2011). Pengaruh Sikap, Norma Subjektif, Kontrol Perilaku yang Dipersepsikan dan Sunset Policy terhadap Kepatuhan Wajib Pajak dengan Niat sebagai Variabel Intervening. Journal Universitas Brawijaya. 